Article

\title{
Activation Mechanism of Lead Ions in Perovskite Flotation with Octyl Hydroxamic Acid Collector
}

\author{
Yu Zheng ${ }^{1}$, Yating Cui ${ }^{1}$ and Weiqing Wang ${ }^{1,2, *}$ \\ 1 School of Environment and Resource, Southwest University of Science and Technology, Mianyang 621010, \\ Sichuan, China; swustzy@126.com (Y.Z.); swustcyt@163.com (Y.C.) \\ 2 Key Laboratory of Solid Waste Treatment and Resource Recycle, Ministry of Education, \\ Southwest University of Science and Technology, Mianyang 621010, Sichuan, China \\ * Correspondence: wangweiqing@swust.edu.cn; Tel.: +86-816-241-9569
}

Received: 5 July 2018; Accepted: 4 August 2018; Published: 8 August 2018

check for updates

\begin{abstract}
The activation mechanism of lead ions $\left(\mathrm{Pb}^{2+}\right)$ in perovskite flotation with an octyl hydroxamic acid collector was systematically investigated using microflotation experiments, zeta-potential measurements, adsorption tests, Fourier transform infrared (FT-IR) analysis, and X-ray photoelectron spectroscopy (XPS) analysis. The results of microflotation experiments and adsorption tests indicate that the presence of $\mathrm{Pb}^{2+}$ can promote the adsorption of octyl hydroxamic acid (OHA) on the perovskite surface and enhance the flotability of perovskite under weakly acidic conditions. The maximum recovery of $79.62 \%$ was obtained at $\mathrm{pH} 6.5$ in the presence of $\mathrm{Pb}^{2+}$, and the maximum recovery of $57.93 \%$ was obtained at $\mathrm{pH} 5.7$ without $\mathrm{Pb}^{2+}$. At $\mathrm{pHs}$ below 7 , lead species are mainly present as $\mathrm{Pb}^{2+}$ and $\mathrm{PbOH}^{+}$in the solution; besides this, the relative content of titanium increases on the perovskite surface. The adsorption of $\mathrm{Pb}^{2+}$ and $\mathrm{PbOH}^{+}$on the perovskite surface makes the zeta-potential of perovskite shift positively, and increases the number of activated sites on the perovskite surface. FT-IR and XPS analyses confirm that OHA chemisorbs on the surface of $\mathrm{Pb}^{2+}$-activated perovskite and forms hydrophobic $\mathrm{Pb}-\mathrm{OHA}$ complexes, which improve the flotability of perovskite.
\end{abstract}

Keywords: perovskite; flotation; octyl hydroxamic acid; lead ions; activation

\section{Introduction}

Titanium and titanium alloys have extensive applications, such as in aerospace, national defense, transportation, medical devices, and national economic production as important strategic resources [1-5]. Ilmenite $\left(\mathrm{TiFeO}_{3}\right)$ is used as the raw material for titanium production because of the relative scarcity of rutile $\left(\mathrm{TiO}_{2}\right)[6,7]$.

More than 95\% of China's titanium resource deposits are distributed over the PanXi area (Panzhihua and Xichang, Sichuan province), which mostly exists in vanadium-titanium magnetite ore $[4,5,8,9]$. When vanadium-titanium magnetite concentrate is smelted in a blast furnace, the titanium is mostly concentrated in the perovskite phase (mainly $\mathrm{CaTiO}_{3}$ ) of blast furnace slag in the process of PanXi iron-smelting. The blast furnace slag is an important synthetic titanium resource, with a $\mathrm{TiO}_{2}$ grade of approximately 20-25\% [10-12]. At present, the annual production of titanium-bearing blast furnace slag is more than $3.0 \times 10^{6}$ tons; a large amount of slag accumulation leads to the waste of titanium resources and serious environmental pollution [13].

Perovskite can be used as a starting ore for titanium production. Some studies have investigated the reduction of Ti metals starting from $\mathrm{CaTiO}_{3}$ instead of $\mathrm{TiO}_{2}$, and obtained success [7,14]. In industry, various methods are used to recycle qualified perovskite product, such as gravity separation, magnetic separation, smelting reduction, and hydrometallurgy $[11,15,16]$. However, because perovskite is 
disseminated in gangue minerals in fine grains $(<10 \mu \mathrm{m})$, flotation separation is the most common method for the effective separation of perovskites from gangue minerals [17]. Previous studies on perovskite have indicated that, compared with ilmenite and rutile, perovskite exhibits poor flotability under typical flotation conditions [1,17].

It has been reported that sodium oleate and sodium lauryl sulfate were used as collectors for perovskite flotation; nonetheless, because of their poor selectivity, it is difficult to separate and recover perovskite effectively [18]. Alkyl hydroxamic acid collectors are widely used for the flotation of iron, tin, and rare earth metal minerals because of their high selectivity [19-25]. For instance, octyl hydroxamic acid (OHA) can be adsorbed on the surface of monazite selectively and recover rare earth oxides from hematite, quartz and calcite [26-29]. In addition, because the reactivity between lead ions and hydroxamic acid collectors is more extreme than other metal ions, lead ions are often used with hydroxamic acid collectors [30]. For example, lead ions can be adsorbed onto an ilmenite surface and complexed with benzohydroxamic acid in solution, which significantly improves the recovery of ilmenite [30]. Previous studies have demonstrated the effectiveness of lead ion activation [31-35]. However, when octyl hydroxamic acid is used as the collector, the effect of lead ions on perovskite flotation has not yet been reported. Herein, $\mathrm{Pb}^{2+}$ is introduced as an activator of perovskite flotation to overcome the poor flotability of perovskites.

The objective of this study is to explore the effects of lead ions on perovskite flotability and the activation mechanism of lead ions in perovskite flotation with octyl hydroxamic acid collector through microflotation experiments, zeta-potential measurements, adsorption tests, FT-IR analysis and XPS analysis.

\section{Materials and Methods}

\subsection{Materials and Reagents}

Because perovskite has a fine grain size $(<10 \mu \mathrm{m})$ and a complex association with gangue minerals in blast furnace slag, it is difficult to separate pure minerals by physical methods [17]. Thus, equivalent amounts of $\mathrm{CaO}$ and $\mathrm{TiO}_{2}$ were mixed and heated at $1350{ }^{\circ} \mathrm{C}$ for $10 \mathrm{~h}$ to obtain perovskite [36]. After being ground and screened, 38-75 $\mu \mathrm{m}$ of powdered samples were used in the flotation experiments [17]. The samples used for the zeta-potential measurements and FT-IR analysis were further ground to about $2 \mu \mathrm{m}$. The chemical composition and X-ray diffraction (XRD) results of the perovskite sample used in the present study are shown in Table 1 and Figure 1, respectively. The results indicate that the prepared perovskite is very pure.

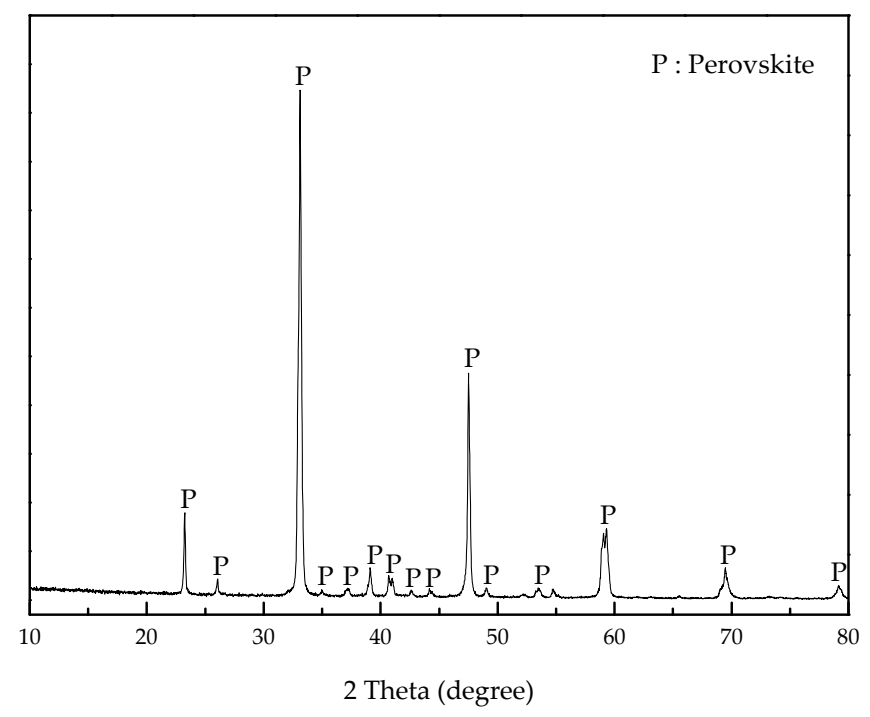

Figure 1. XRD spectrum of perovskite sample. 
Table 1. Chemical composition of perovskite sample (mass fraction, \%).

\begin{tabular}{cccc}
\hline Sample & $\mathrm{TiO}_{2}$ & $\mathrm{CaO}$ & Total \\
\hline Perovskite & 58.77 & 41.23 & 100.00 \\
\hline
\end{tabular}

In this study, the OHA collector and activator $\mathrm{Pb}\left(\mathrm{NO}_{3}\right)_{2}$ were chemically pure. Perovskite was washed to neutrality with deionized water and then dried at $60{ }^{\circ} \mathrm{C}$ before flotation. Hydrochloric acid $(\mathrm{HCl})$ and sodium hydroxide $(\mathrm{NaOH})$ were used to adjust the $\mathrm{pH}$ of the system. Deionized water (resistivity: $18.25 \mathrm{M} \Omega \cdot \mathrm{cm}$ ) was used for the microflotation experiments and subsequent measurements.

\subsection{Microflotation Experiments}

Microflotation experiments were conducted in a $40 \mathrm{~mL}$ hitch groove flotation cell. At first, $2.0 \mathrm{~g}$ of the mineral sample and $35 \mathrm{~mL}$ of deionized water were placed in the plexiglass cell and then agitated for $1 \mathrm{~min}$. Next, the $\mathrm{pH}$ of the pulp was adjusted by $\mathrm{HCl}$ or $\mathrm{NaOH}$ and agitated for $3 \mathrm{~min}$. Then, the $\mathrm{Pb}\left(\mathrm{NO}_{3}\right)_{2}$ was added and agitated for an additional $3 \mathrm{~min}$. After that, the OHA was added and agitated for $3 \mathrm{~min}$, and the $\mathrm{pH}$ of the suspension was recorded before the collection. Finally, the froth products were collected for $4 \mathrm{~min}$. The recoveries were calculated based on the dry weight of products. Three measurements in the microflotation experiments were performed, and the averages were recorded.

\subsection{Zeta-Potential Measurements}

The zeta-potentials were measured using a Zetasizer Nano Zs90 (Malvern Instruments, Malvern, UK) at room temperature $\left(25^{\circ} \mathrm{C}\right)$. The zeta-potentials were monitored continuously based on the conductivity and $\mathrm{pH}$ of the suspension during the measurements. Thirty milligrams of the perovskite sample was put into $50 \mathrm{~mL}$ of electrolyte solution $(1 \mathrm{mM} \mathrm{KCl})$ to prepare the suspensions. The prepared suspension was conditioned by magnetic stirring for $5 \mathrm{~min}$, during which the $\mathrm{pH}$ of the suspension was measured. After settling for $10 \mathrm{~min}$, the supernatant of the dilute fine particle suspension was obtained for zeta-potential measurements. The final results were averaged over three measurements.

\subsection{FT-IR Spectroscopy Analysis}

The FT-IR spectra were obtained from 4000 to $400 \mathrm{~cm}^{-1}$ using a Spectrum One (version BM) spectrometer (Perkin Elmer, Waltham, MA, USA) at $25^{\circ} \mathrm{C}$. Two grams of the perovskite sample was ground to a diameter of less than $2 \mu \mathrm{m}$, and then combined with suitable reagents in a plexiglass cell and conditioned for $40 \mathrm{~min}$. Subsequently, the solid sample was washed three times using deionized water at the same $\mathrm{pH}$. The washed samples for FT-IR analysis were vacuum-dried at $60^{\circ} \mathrm{C}$. Approximately $5 \%$ (mass fraction) of the solid sample was mixed with spectroscopic grade $\mathrm{KBr}$ to obtain the spectra of the solids.

\subsection{Adsorption Tests}

The amount of OHA adsorbed on the surface of perovskite was determined at $25{ }^{\circ} \mathrm{C}$ by spectrophotometer (UV-2600, Shimadzu, Kyoto, Japan). First, $2.0 \mathrm{~g}$ of mineral sample and $35 \mathrm{~mL}$ of deionized water were placed in the plexiglass cell, and then the reagents were added into the suspension. Next, the suspension was fixed to $50 \mathrm{~mL}$ with deionized water. The suspension was shaken at $25{ }^{\circ} \mathrm{C}$ for $12 \mathrm{~h}$. The supernatant of the dilute fine particle suspension was obtained for adsorption tests. The adsorbed amount of $\mathrm{OHA}$ on the perovskite surface was calculated using the following Equation (1):

$$
\Gamma=\left(C_{0}-C\right) \times V /(m A),
$$

where $\Gamma$ is the adsorbed amount of OHA on the perovskite surface $\left(\mathrm{mol} / \mathrm{m}^{2}\right) ; C_{0}$ and $C$ are the concentrations of OHA in initial and supernatant, respectively (mol/L); $V$ is the volume of the solution 
(L); $m$ is the weight of perovskite particles (g); and $A$ is the mineral specific surface area $\left(\mathrm{m}^{2} / \mathrm{g}\right)$. The final results were averaged over three measurements.

\subsection{XPS Analysis}

A Kratos AXIS Ultra XPS system equipped with a monochromatic Al X-ray source, operated at $150 \mathrm{~W}$ (the energy resolution is $0.48 \mathrm{eV}(\mathrm{Ag} 3 \mathrm{~d} 5 / 2)$ and the error value is $0.05 \mathrm{eV})$, was used to perform XPS measurements. Survey scans were conducted in a single sweep from 0 to $1350 \mathrm{eV}$, with a dwell time of $8 \mathrm{~s}$, a passing energy of $150 \mathrm{eV}$, and a 1-eV step size. For high-resolution scanning, the number of scans was increased, the dwell time was reduced to $0.5 \mathrm{~s}$, and the band pass energy was adjusted to $30 \mathrm{eV}$. The purified mineral particles $(2.0 \mathrm{~g})$ and deionized water $(35 \mathrm{~mL})$ were placed in the plexiglass cell, and then adjusted with appropriate reagents. Subsequently, the solid samples were washed three times with deionized water. The washed samples for XPS analysis were vacuum-dried at $60{ }^{\circ} \mathrm{C}$.

\section{Results}

\subsection{Microflotation Experiments}

Figure 2 shows the flotation recovery of the perovskite as functions of $\mathrm{pH}$ using $\mathrm{OHA}$ as the collector in the presence and absence of $\mathrm{Pb}^{2+}$. The recovery of perovskite first increased and then decreased with increasing $\mathrm{pH}$ in the presence and absence of $\mathrm{Pb}^{2+}$. When only $\mathrm{OHA}$ was used, the flotation recovery reached a maximum of about $57.93 \%$ at approximately $\mathrm{pH} 5.70$. However, after adding $\mathrm{Pb}^{2+}$ into the slurry, the flotation recovery was significantly increased throughout the investigated $\mathrm{pH}$ range, and the maximum recovery of $79.62 \%$ occurred at approximately $\mathrm{pH} 6.5$. The results indicate that the presence of $\mathrm{Pb}^{2+}$ has a positive effect on the perovskite flotation using $\mathrm{OHA}$.

Figure 3 displays the effect of $\mathrm{Pb}^{2+}$ concentration on perovskite flotation recovery. With the increase of $\mathrm{Pb}^{2+}$ concentration, the flotation recovery of perovskite increased gradually and achieved $79.62 \%$ at $\mathrm{Pb}^{2+}$ concentration of $0.1 \mathrm{mM}$. After that, the flotation recovery of perovskite showed no obvious change when $\mathrm{Pb}^{2+}$ concentration was more than $0.1 \mathrm{mM}$. Thus, the optimum conditions $\left(\mathrm{Pb}^{2+}\right.$ concentration: $\left.0.1 \mathrm{mM}, \mathrm{pH}: 6.54\right)$ for perovskite flotation determined by flotation results could be used for subsequent experiments.

Previous studies have shown that in a weakly acidic environment, calcium ions on the perovskite surface are largely dissolved into the slurry, and titanium on the perovskite surface becomes the main site for hydroxamic acid [17]. Compared with calcium ions, titanium ions and hydroxamic acid have a stronger effect [37-39]. These factors explain why the highest flotation recovery is under weak acidic conditions when OHA is used as a collector for perovskite.

According to the ionization constant $\mathrm{pK}_{\alpha}$ of $\mathrm{OHA} \cong 9[17,40]$, the concentration logarithmic of each component in different $\mathrm{pH}$ solutions of $\mathrm{OHA}$ can be calculated. The logarithmic diagram of $\mathrm{OHA}$ hydrolysis components as functions of $\mathrm{pH}$ when the OHA concentration is $0.2 \mathrm{mM}$ are presented in Figure 4. It can be seen that the molecular OHA concentration decreases and the concentration of ionic OHA increases as the $\mathrm{pH}$ of the pulp increases. When the $\mathrm{pH}$ is less than 9, the OHA molecule is the main component in the flotation slurry, and the OHA anion is the minor component. In OHA solution, $\mathrm{OHA}$ anions and OHA molecules can be adsorbed on the mineral surface, they can chelate with the metal cations on the mineral surface, and the nonpolar part of $\mathrm{OHA}$ species can be adsorbed on the nonpolar part of the former OHA species through hydrogen bonds $[17,19]$.

Therefore, at a $\mathrm{pH}$ of about 6.5, the multi-layer adsorption of OHA species and the relative increase of the perovskite surface's active metal cations significantly increase the flotability of the perovskite [39-43]. 


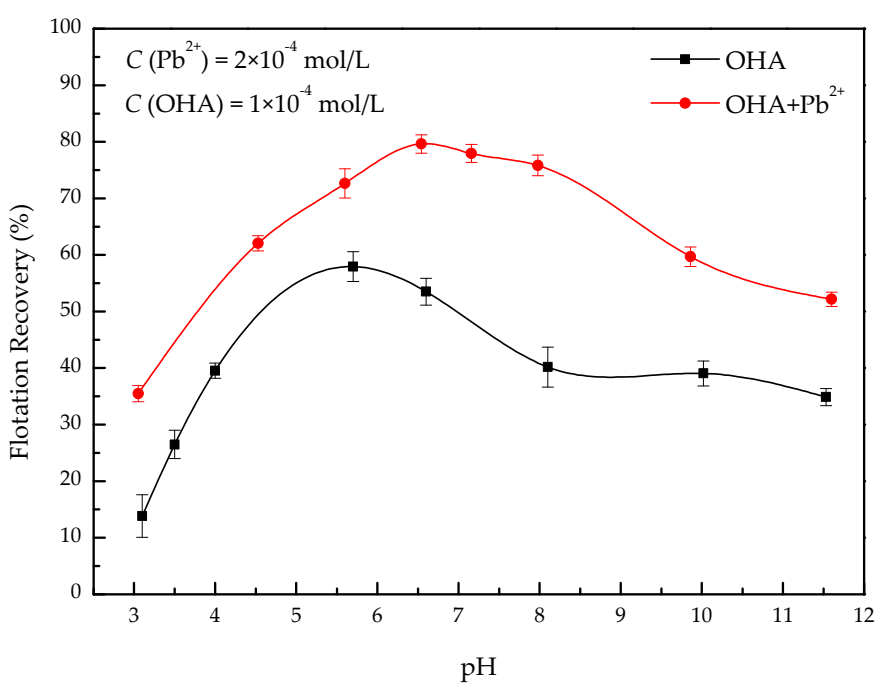

Figure 2. Effects of $\mathrm{pH}$ on perovskite flotation recovery in the absence and presence of $\mathrm{Pb}^{2+}$.

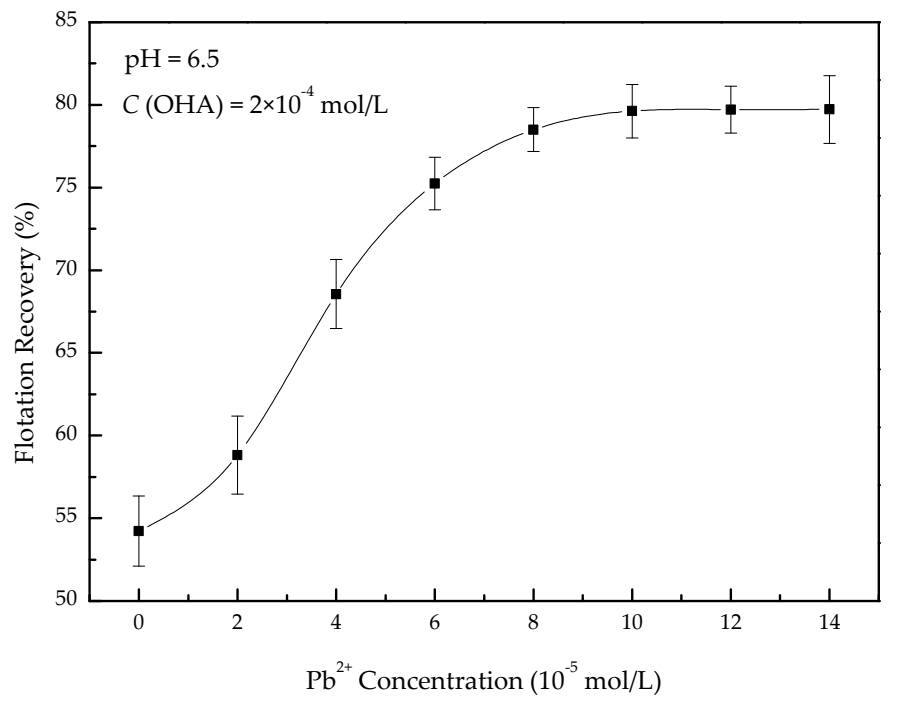

Figure 3. Effects of $\mathrm{Pb}^{2+}$ concentration on perovskite flotation recovery.

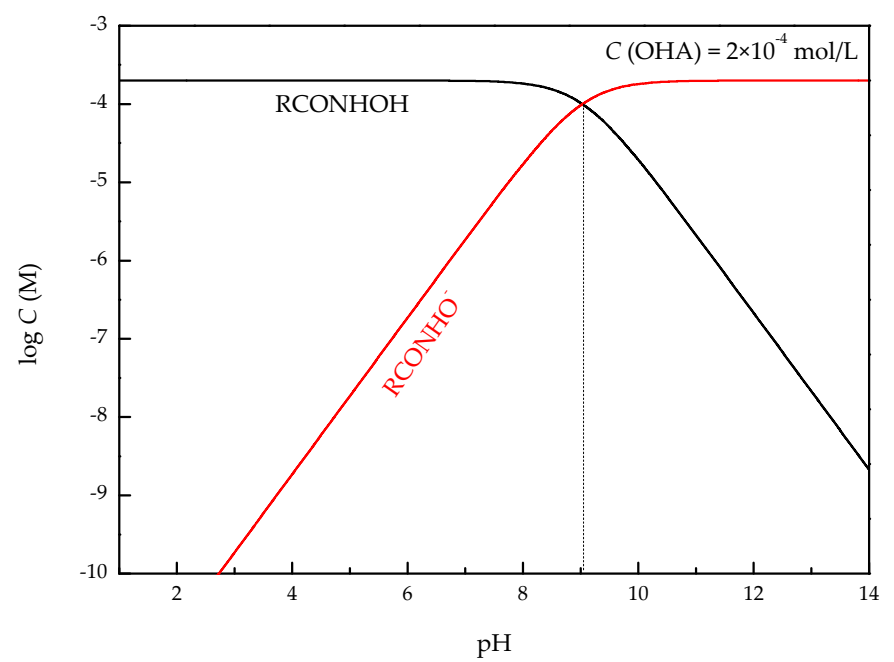

Figure 4. Logarithmic diagram of octyl hydroxamic acid (OHA) hydrolysis components. 


\subsection{Zeta-Potential Measurements}

Figure 5 presents the effect of $\mathrm{Pb}^{2+}$ and $\mathrm{OHA}$ on the zeta-potential of perovskite. The isoelectric point (IEP) of perovskite was found to be $\mathrm{pH} 4.1$, which is in accordance with previous reports [17]. After the OHA was added to the slurry, the zeta-potential of the perovskite was reduced, and the isoelectric point was moved to 2.9. Therefore, it could be concluded that a specific adsorption of OHA species on the perovskite surface occurred. The research has shown that the adsorption of OHA on the perovskite surface may occur through chemical adsorption $[17,30]$. When $\mathrm{Pb}^{2+}$ was added to the suspension, the zeta-potential increased significantly at the investigated $\mathrm{pH}$, and the maximum zeta-potential was observed at $\mathrm{pH}$ 7.3.

According to the solubility product $\mathrm{pK}_{\mathrm{sp}}$ of $\mathrm{Pb}^{2+} \cong 15.2[30,43]$, the solution chemistry of $\mathrm{OHA}$ can be calculated to generate the concentration logarithmic diagram of each component in different $\mathrm{pH}$ solutions. Figure 6 shows the $\log \mathrm{C}-\mathrm{pH}$ of the $\mathrm{Pb}^{2+}$ hydrolysis components as functions of $\mathrm{pH}$ when the $\mathrm{Pb}^{2+}$ concentration is $0.1 \mathrm{mM}$. It can be observed from Figure 6 that lead is mainly present as $\mathrm{Pb}^{2+}$ at low $\mathrm{pHs}$. As the $\mathrm{pH}$ increased, the concentration of $\mathrm{PbOH}^{+}$increased gradually. Previous studies have shown that $\mathrm{Pb}^{2+}$ and $\mathrm{PbOH}^{+}$have a high activity and are adsorbed on the surface of minerals by chemical adsorption $[21,30]$. When the $\mathrm{pH}$ was 6-9, the concentrations of $\mathrm{PbOH}^{+}$and $\mathrm{Pb}^{2+}$ are both high; this might explain why the maximum zeta-potential is at $\mathrm{pH}$ 7.3. In the presence of $\mathrm{Pb}^{2+}$ and OHA, the perovskite zeta-potential is lower than the zeta-potential in deionized water, but higher than OHA alone. Obviously, both lead ions and OHA are adsorbed on the perovskite surface. In addition, lead species that are adsorbed on the mineral surface act as reaction sites and can be chelated by $\mathrm{OHA}[30,43]$. Meanwhile, the remaining lead in the solution will react with $\mathrm{OHA}$ to form a Pb-OHA complex that can be adsorbed on the surface of the perovskite and increase its hydrophobicity [30,44]. This is in accordance with the results of microflotation experiments.

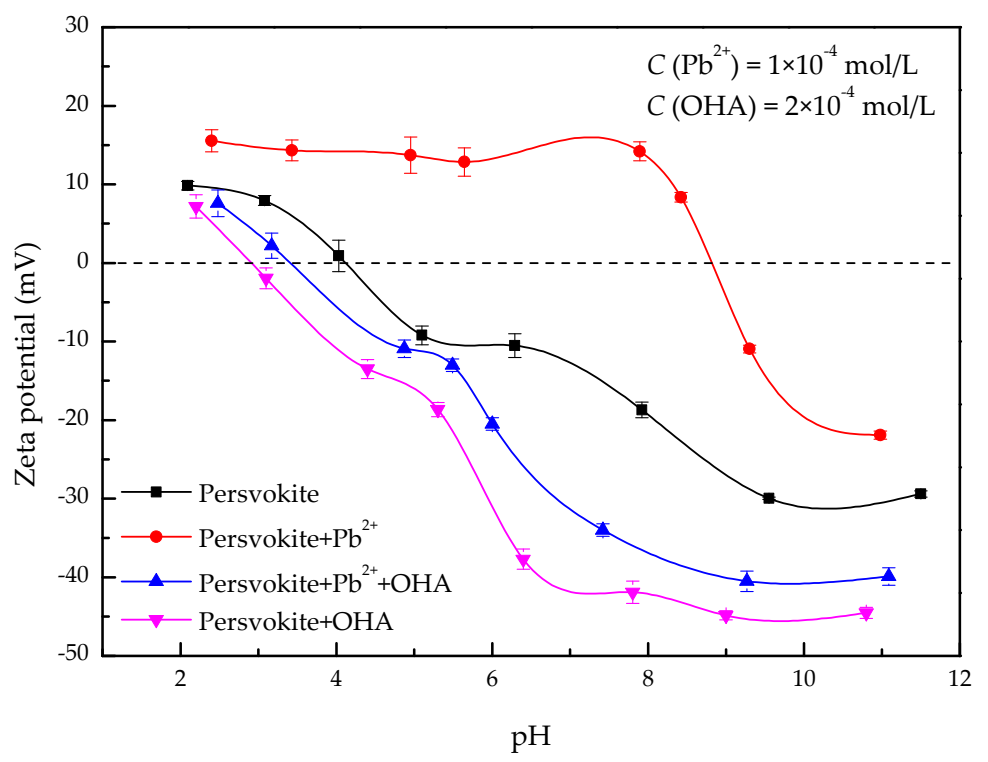

Figure 5. Zeta-potentials of perovskite as a function of $\mathrm{pH}$. 


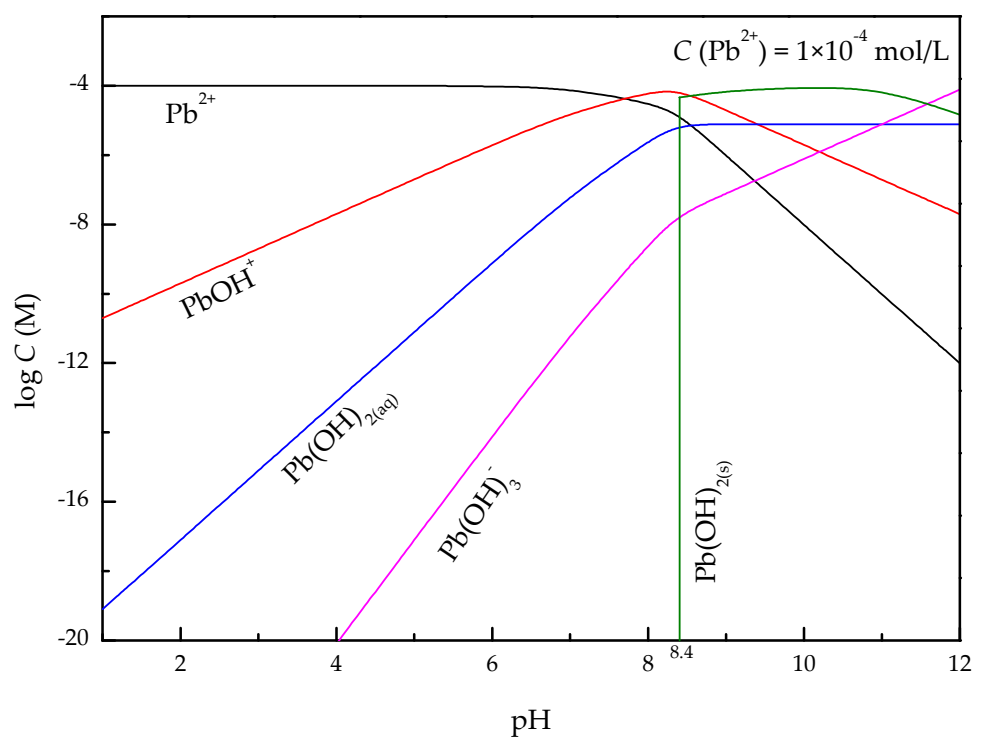

Figure 6. Logarithmic diagram of lead ions hydrolysis components.

\subsection{Adsorption Tests}

Figure 7 shows the effect of $\mathrm{Pb}^{2+}$ on adsorption of $\mathrm{OHA}$ on the perovskite surface. In the absence of $\mathrm{Pb}^{2+}$, the effect of $\mathrm{pH}$ on $\mathrm{OHA}$ adsorption was not obvious; the adsorbance firstly increased, and then decreased with the increase of $\mathrm{pH}$. In the presence of $\mathrm{Pb}^{2+}$, the OHA adsorption increased significantly with increasing $\mathrm{pH}$, and the maximum adsorbance was reached at around $\mathrm{pH}$ 6.5. This can explain the results of the microflotation experiments. The results of the adsorption tests show that after activation with lead ions, the OHA adsorbance on the perovskite surface significantly increases in the investigated $\mathrm{pH}$ range, which indicates that the lead ions promote the adsorption of OHA on the perovskite surface. This may be attributed to an increase in the number of active sites and the formation of more stable $\mathrm{Pb}-\mathrm{OHA}$ species on the perovskite surface $[43,44]$.

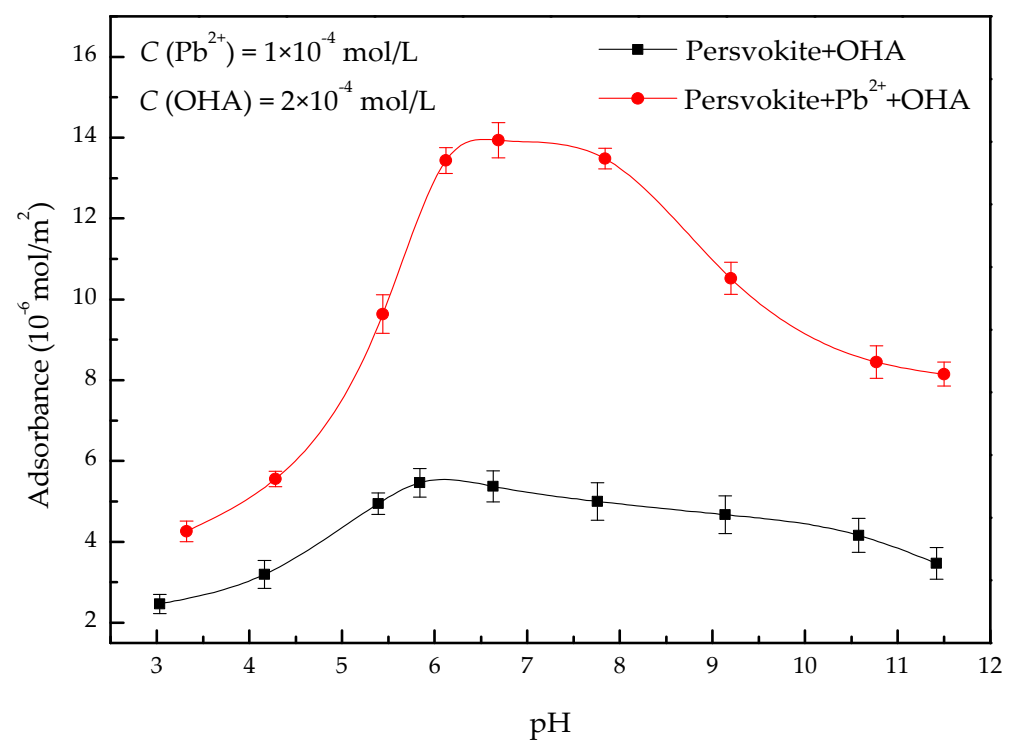

Figure 7. OHA adsorbance on the surface of perovskite as a function of $\mathrm{pH}$. 


\subsection{FT-IR Analysis}

Figure 8 shows the FT-IR spectra of perovskite before and after adjustment with different agents. In the infrared spectrum of OHA, the peak at $3248 \mathrm{~cm}^{-1}$ was due to the overlap of $\mathrm{N}-\mathrm{H}$ and $-\mathrm{OH}$ stretching vibrations. The peaks at 3060 and $1561 \mathrm{~cm}^{-1}$ were attributed to the stretching vibration of $\mathrm{N}-\mathrm{H}$. Besides this, the peaks at 2944, 2915, 2846, 1467, 1423, and $722 \mathrm{~cm}^{-1}$ were related to the stretching or bending vibrations of $-\mathrm{CH}_{3}$ and $-\mathrm{CH}_{2}$. Moreover, the peaks at $2763,1659,1620$, and $1116 \mathrm{~cm}^{-1}$ were derived from the stretching vibrations of $-\mathrm{OH}, \mathrm{C}=\mathrm{O}, \mathrm{C}=\mathrm{N}$, and $\mathrm{C}=\mathrm{O}$. In addition, the absorption bands near $2400 \mathrm{~cm}^{-1}$ were characteristic of molecules containing long alkyl chains, because these bands came from the symmetrical and asymmetric stretching vibrations of the $-\mathrm{CH}_{2}-$ group. The absorption bands at 1077, 1030, and $969 \mathrm{~cm}^{-1}$ correspond to $\mathrm{N}-\mathrm{O}$ stretching vibrations.

The infrared spectrum of perovskite shows two major bands at 565 and $448 \mathrm{~cm}^{-1}$ which belong to the characteristic peaks of Ti-O stretching and Ti-O-Ti bridge stretching modes. After treatment with OHA, the new peaks at $2919 \mathrm{~cm}^{-1}$ and $2851 \mathrm{~cm}^{-1}$ were related to the stretching vibration of $\mathrm{C}-\mathrm{H}$, and the band at $1448.9 \mathrm{~cm}^{-1}$ was the $\mathrm{C}-\mathrm{H}$ antisymmetric deformation vibration of the $-\mathrm{CH}_{3}$ group. The peak at $1116 \mathrm{~cm}^{-1}$ was the $\mathrm{C}=\mathrm{O}$ stretching vibration. There was no significant change in these bands, but it was shown that OHA is adsorbed on the perovskite surface. The band at $1630 \mathrm{~cm}^{-1}$ was the stretching vibration of $\mathrm{C}=\mathrm{O}$, and that at $875 \mathrm{~cm}^{-1}$ was the stretching vibration of $\mathrm{N}-\mathrm{O}$. In addition, the shift of these peaks proves that OHA is adsorbed on the surface of the perovskite by chemical adsorption.

Infrared spectroscopy of the perovskite after treatment with lead ions and OHA shows that the stretching vibration peak of $\mathrm{OH}$ at $3433 \mathrm{~cm}^{-1}$ was significantly reduced, which contributed to the possible formation of metal coordination bonds. Furthermore, a new peak appeared at $2983 \mathrm{~cm}^{-1}$, which corresponded to the asymmetric stretching vibration of $-\mathrm{CH}_{3}$. In addition, the peak shifts at $1619 \mathrm{~cm}^{-1}$ and $1429 \mathrm{~cm}^{-1}$ were more significant, and the peaks at 2924, 2854, 1619, 1429, and $1124 \mathrm{~cm}^{-1}$ were more intense. Therefore, it can be speculated that the addition of $\mathrm{Pb}^{2+}$ enhances the adsorption of OHA on the perovskite surface.

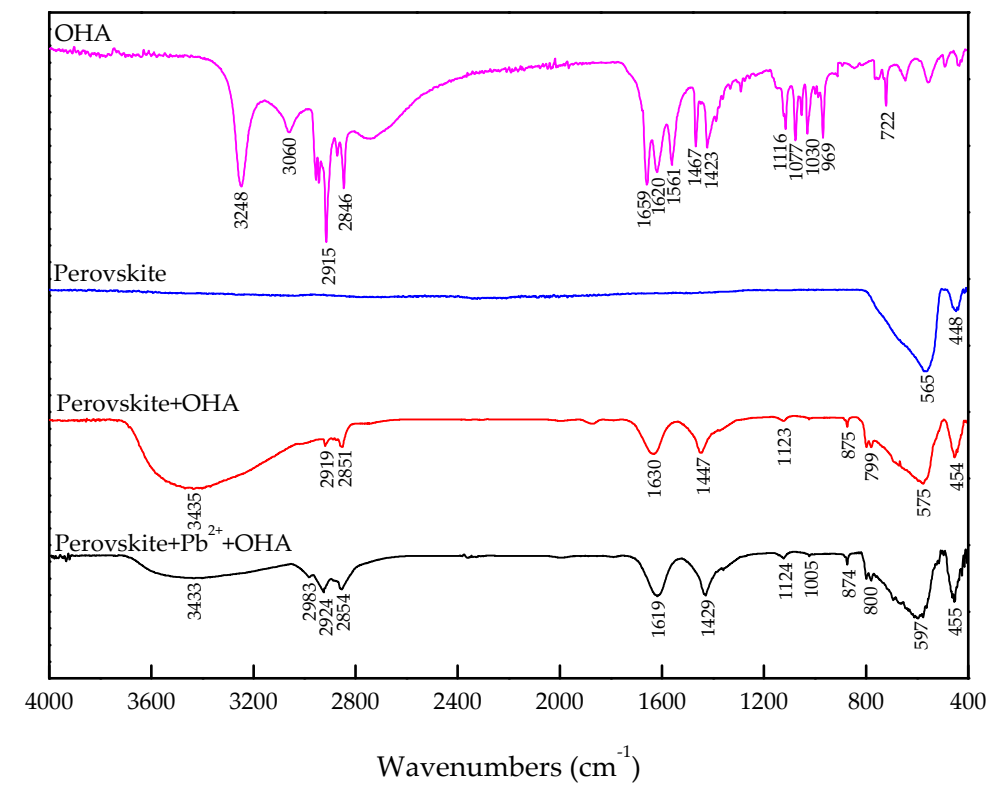

Figure 8. FT-IR spectra of perovskites before and after adjustment with different agents.

\subsection{XPS Analysis}

To further determine the interaction mechanism between $\mathrm{OHA}$ and perovskite activated with $\mathrm{Pb}^{2+}$, an XPS analysis of perovskite conditioned with $\mathrm{Pb}^{2+}$ ions or/and $\mathrm{OHA}$ was conducted. The relative 
contents of the elements on the perovskite surface are summarized in Table 2. Table 2 shows that the Ti2p relative contents of the perovskite surface increased from $11.02 \%$ under a neutral condition, and to $13.48 \%$ under a weak acidic condition. Therefore, weak acidic conditions can increase the relative content of titanium sites on the perovskite surface. In addition, the $\mathrm{Pb} 4 \mathrm{f}$ relative contents of the $\mathrm{Pb}^{2+}$-activated perovskite surface reached $0.44 \%$, indicating that $\mathrm{Pb}^{2+}$ was successfully adsorbed on the perovskite surface. Furthermore, when OHA was added alone, the C1s and N1s relative contents were $49.37 \%$ and $0.55 \%$. However, when perovskite was treated with $\mathrm{Pb}^{2+}$ and $\mathrm{OHA}$, the relative contents of $\mathrm{C} 1 \mathrm{~s}$ and $\mathrm{N} 1 \mathrm{~s}$ increased by $9.07 \%$ and $0.31 \%$, respectively. Thus, the adsorption of OHA is promoted by $\mathrm{Pb}^{2+}$.

Tables (Tables 3 and 4) present the binding energies and chemical shifts of elements on perovskite surfaces, respectively. After $\mathrm{Pb}^{2+}$ activation, the binding energies of Ti2p, Ca2p and O1s were shifted by $-0.73,+0.07$ and $+0.35 \mathrm{eV}$, evidencing that the presence of $\mathrm{Pb}^{2+}$ changed the chemical circumstances of $\mathrm{Ti}$ and $\mathrm{O}$ species on the perovskite surface. When perovskite was treated with $\mathrm{Pb}^{2+}$ and $\mathrm{OHA}$, the chemical shift of Ti2p was more significant, and significant chemical shifts were observed for $\mathrm{Pb} 4 \mathrm{f}(-0.43 \mathrm{eV})$ and $\mathrm{N} 1 \mathrm{~s}(+0.71 \mathrm{eV})$ of perovskite treated with both $\mathrm{Pb}^{2+}$ and $\mathrm{OHA}$, compared to that conditioned with $\mathrm{Pb}^{2+}$ or $\mathrm{OHA}$ alone. These confirm that more significant chemical reactions occur, and that the OHA could interact with lead species adsorbed on the surface of perovskite. This corresponds with the binding energy of $\mathrm{Ca} 2 \mathrm{p}$, which showed no obvious change after $\mathrm{Pb}^{2+}$ and OHA treatment.

The high-resolution XPS spectra of perovskite before and after $\mathrm{Pb}^{2+}$ and $\mathrm{OHA}$ treatment are shown in Figure 9. Figure 9a shows that the Ti2p3/2 peaks of pure perovskite appeared at around $458 \mathrm{eV}$, corresponding to the $\mathrm{Ti}^{4+}$ oxidation state [43]. After $\mathrm{Pb}^{2+}$ activation, the Ti2p3/2 binding energy decreased by $0.73 \mathrm{eV}$. The presence of $\mathrm{Pb}^{2+}$ ions changed the chemical circumstance of Ti species on the perovskite surface. Besides this, the addition of OHA further decreased the Ti2p3/2 binding energy to $457.71 \mathrm{eV}$, suggesting that OHA might bond with the Ti species of perovskite surfaces. Comparing with the N1s spectra without adding $\mathrm{Pb}^{2+}$ (Figure $9 \mathrm{~b}$ ), the N1s spectra treated by $\mathrm{Pb}^{2+}$ presented new peaks at $401.65 \mathrm{eV}$, which could be attributed to chemisorbed hydroxamates interacting with lead. The O1s XPS spectra recorded from pure perovskite, perovskite treated with $\mathrm{Pb}^{2+}$, and perovskite treated with both $\mathrm{Pb}^{2+}$ and $\mathrm{OHA}$ are shown in Figure 9c. The O1s peaks are composed of three components. The peaks at around $530.0 \mathrm{eV}$ are attributed to $\mathrm{Ti}-\mathrm{O} / \mathrm{Ti}-\mathrm{O}-\mathrm{Pb}$ bonds $[45,46]$, that at $531.5 \mathrm{eV}$ attributed to Ca-O bonds [43,47], and that at $532.1 \mathrm{eV}$ for hydroxyl bonded to metal ions (Me-OH) [46], respectively. The relative intensity of O1s peaks belonging to Ti-O bonds increased from $59.16 \%$ of pure perovskite to $59.60 \%$ of perovskite modified by $\mathrm{Pb}^{2+}$ and $63.55 \%$ of $\mathrm{Pb}^{2+}$-activated perovskite treated with $\mathrm{OHA}$, while that of $\mathrm{O}-\mathrm{H}$ bonds decreased from $14.23 \%$ to $11.41 \%$ and further to $7.40 \%$. These results illustrated that lead species would interact with active Ti sites to form lead-containing complexes (Ti-O-Pb) on the perovskite surface. Consequently, lead species adsorbed on perovskite surfaces rendered new active sites for $\mathrm{OHA}$ adsorption. OHA replaced $\mathrm{OH}^{-}$ions and bonded to the active metal sites in the form of metal-hydroxamate chelate complexes, improving the hydrophobicity of perovskite.

Table 2. Relative contents of elements on the perovskite surface.

\begin{tabular}{ccccccc}
\hline \multirow{2}{*}{ Sample } & \multicolumn{6}{c}{ Surface Atomic Composition (\%) } \\
\cline { 2 - 7 } & C1s & Ti2p & Ca2p & O1s & Pb4f & N1s \\
\hline Perovskite & 43.18 & 11.02 & 7.72 & 36.69 & - & - \\
Perovskite $(\mathrm{pH}=6.5)$ & 33.37 & 13.48 & 8.49 & 43.10 & - & - \\
Perovskite $+\mathrm{Pb}^{2+}(\mathrm{pH}=6.5)$ & 37.64 & 12.58 & 8.35 & 39.86 & 0.44 & \\
Perovskite $+\mathrm{OHA}(\mathrm{pH}=6.5)^{\mathrm{O}=} \mathrm{49.37}$ & 10.05 & 6.43 & 32.02 & & 0.55 \\
Perovskite $+\mathrm{Pb}^{2+}+\mathrm{OHA}(\mathrm{pH}=6.5)$ & 58.44 & 8.08 & 5.33 & 26.24 & 0.52 & 0.86 \\
\hline
\end{tabular}


Table 3. Binding energies of elements on the perovskite surface.

\begin{tabular}{ccccccc}
\hline \multirow{2}{*}{ Sample } & \multicolumn{6}{c}{ Binding Energy (eV) } \\
\cline { 2 - 7 } & C1s & Ti2p & C1s & O1s & C1s & N1s \\
\hline Perovskite & 284.78 & 458.58 & 346.48 & 529.58 & - & - \\
Perovskite $+\mathrm{Pb}^{2+}$ & 284.77 & 457.85 & 346.55 & 529.93 & 138.50 & - \\
Perovskite + OHA & 284.73 & 458.07 & 346.57 & 529.83 & - & 399.98 \\
Perovskite + $\mathrm{Pb}^{2+}+$ OHA & 284.75 & 457.71 & 346.54 & 529.85 & 138.16 & 400.69 \\
\hline
\end{tabular}

Table 4. Chemical shifts of the elemental binding energies of the perovskite surface.

\begin{tabular}{ccccccc}
\hline Sample & \multicolumn{6}{c}{ Chemical Shift (eV) } \\
\cline { 2 - 7 } & C1s & Ti2p & Ca2p & O1s & Pb4f & N1s \\
\hline Perovskite $+\mathrm{Pb}^{2+}$ & -0.01 & -0.73 & +0.07 & +0.35 & - & - \\
Perovskite $+\mathrm{OHA}^{2+}$ & -0.05 & -0.51 & +0.09 & +0.25 & - & - \\
Perovskite $+\mathrm{Pb}^{2+}+\mathrm{OHA}$ & -0.03 & -0.87 & +0.06 & +0.27 & -0.34 & +0.71 \\
\hline
\end{tabular}
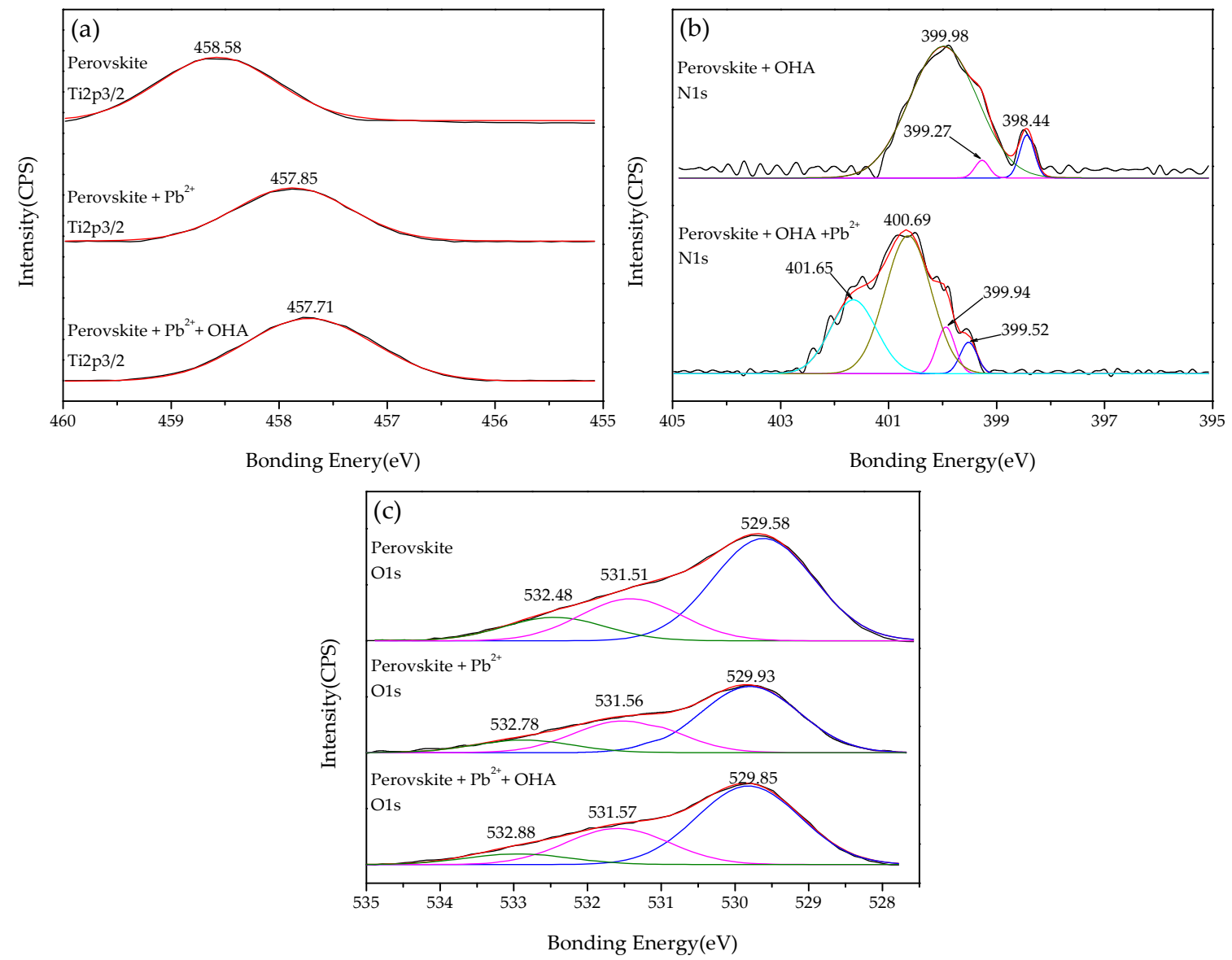

Figure 9. High-resolution XPS spectra of perovskite before and after $\mathrm{Pb}^{2+}$ and $\mathrm{OHA}$ treatment: (a) Ti2p, (b) N1s, (c) O1s. (Black line: original curve, red line: fitted curve, other colors line: curve of XPS-peak-differentiation-imitating analysis)

\section{Discussion}

According to the experimental results and analyses, the presence of $\mathrm{Pb}^{2+}$ can promote the adsorption of OHA and enhance the flotability of perovskite. The results of microflotation and adsorption tests indicate that the presence of $\mathrm{Pb}^{2+}$ can promote the adsorption of OHA on the perovskite 
surface and enhance the flotability of perovskite in a wide $\mathrm{pH}$ range. The zeta-potential analysis shows that specific adsorption of OHA and lead species on the perovskite surface can occur. The adsorption of $\mathrm{Pb}^{2+}$ and $\mathrm{PbOH}^{+}$on the perovskite surface makes the zeta-potential of perovskite shift positively in the $\mathrm{pH}$ range from 6.0 to 7.0, which is in agreement with the results of microflotation and adsorption tests. The FT-IR results give further evidence that $\mathrm{OHA}$ can chemisorb onto the surface of perovskite, and that the addition of $\mathrm{Pb}^{2+}$ can enhance the adsorption of OHA on the perovskite surface. The XPS analysis shows that the addition of $\mathrm{Pb}^{2+}$ can change the chemical circumstances of Ti and $\mathrm{O}$ species on the perovskite surface. When perovskite is treated with both $\mathrm{Pb}^{2+}$ and $\mathrm{OHA}$, the binding energies of Ti2p, Pb4f, O1s and N1s present significant shifts $(0.27-0.87 \mathrm{eV})$. Thus, it can be inferred that the $\mathrm{Pb}^{2+}$ and $\mathrm{PbOH}^{+}$are adsorbed onto the surface of perovskite, which increases the number of activated sites. Then, the $\mathrm{OHA}$ molecules and anions would chelate with $\mathrm{Ti}$ or $\mathrm{Pb}$ on the perovskite surface; besides this, the nonpolar part of the OHA species adsorbs the former OHA species by a hydrogen bond, which is consistent with the results of the zeta-potentials and FT-IR.

Based on these results, it can be concluded that $\mathrm{Pb}^{2+}$ can promote perovskite flotation effectively by using OHA as collector. It can be considered that the lead species are adsorbed on the perovskite surface first, and then the $\mathrm{Ti}$ and $\mathrm{Pb}$ reacted with $\mathrm{OHA}$ to form hydrophobic species of metal-OHA complexes; besides this, the nonpolar part of the OHA species adsorb the former OHA species by a hydrogen bond. This promotes the adsorption of OHA on the perovskite surface and enhances the flotability of perovskite. The adsorption model of $\mathrm{Pb}^{2+}$ and OHA on the perovskite surface in Figure 10 reveals the potential mechanism of $\mathrm{Pb}^{2+}$ activation and $\mathrm{OHA}$ adsorption.

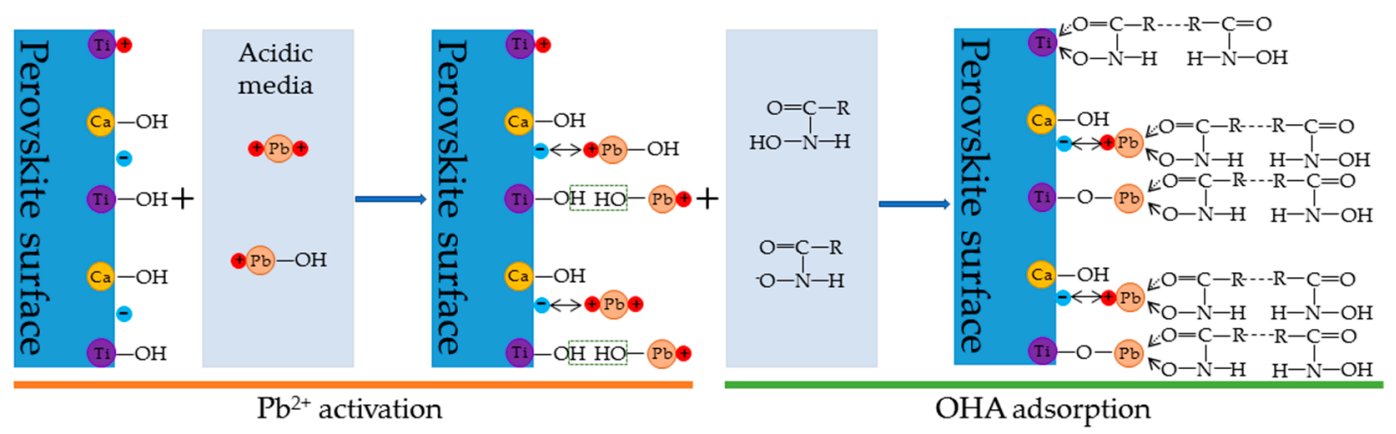

Figure 10. Proposed adsorption model of $\mathrm{Pb}^{2+}$ and $\mathrm{OHA}$ on the perovskite surface.

\section{Conclusions}

1. In the present study, the effects of lead ions on the perovskite flotability and the activation mechanism of lead ions in perovskite flotation with an octyl hydroxamic acid collector were investigated using microflotation experiments, zeta-potential measurements, adsorption tests, FT-IR, and XPS analyses. The results of microflotation and adsorption tests indicate that the presence of $\mathrm{Pb}^{2+}$ can promote the adsorption of $\mathrm{OHA}$ on the perovskite surface and enhance the flotability of perovskite in a wide $\mathrm{pH}$ range. In addition, maximum recovery of $79.62 \%$ could be obtained at $\mathrm{pH} 6.5$ in the presence of $\mathrm{Pb}^{2+}$.

2. The zeta-potential shows that specific adsorption of OHA and lead species on the perovskite surface can occur. FT-IR and XPS measurements indicate that the adsorption of lead ions on the perovskite surface is mainly chemical adsorption. FT-IR analysis gives further evidence that the lead species react with titanium hydroxyl compounds on the perovskite surface to form lead complexes, which are the main active sites for OHA adsorption. Meanwhile, FT-IR and XPS analyses confirm that $\mathrm{OHA}$ chemisorbs on the surface of $\mathrm{Pb}^{2+}$-activated perovskite and forms hydrophobic $\mathrm{Pb}-\mathrm{OHA}$ complexes, and then the nonpolar part of OHA species molecules will adsorb the nonpolar part of the former OHA species through hydrogen bonds to form multi-layer adsorption. This adsorption mode improves the flotability of perovskite. 
Author Contributions: W.W. and Y.Z. conceived and designed the experiments; Y.Z. performed the experiments; Y.Z. and Y.C. analyzed the data; W.W. contributed reagents and materials; Y.Z. wrote the paper.

Funding: This research was funded by [Fund of the State Key Laboratory of Mineral Processing] grant number [BGRIMM-KJSKL-2015-07], [the Opening Project of Key Laboratory of Solid Waste Treatment and Resource Recycling, Ministry of Education] grant number [13zxsk06], [Postgraduate Innovation Fund Project of the Southwest University of Science and Technology] grant number [18ycx044]. And the APC was funded by [Southwest University of Science and Technology].

Acknowledgments: This study was financially supported by the Fund of the State Key Laboratory of Mineral Processing (BGRIMM-KJSKL-2015-07), the Opening Project of Key Laboratory of Solid Waste Treatment and Resource Recycling, Ministry of Education (13zxsk06), and the Postgraduate Innovation Fund Project of the Southwest University of Science and Technology (18ycx044).

Conflicts of Interest: The authors declare no conflict of interest.

\section{References}

1. Bulatovic, S.; Wyslouzil, D.M. Process development for treatment of complex perovskite, ilmenite and rutile ores. Miner. Eng. 1999, 12, 1407-1417. [CrossRef]

2. Chen, D.S.; Zhao, L.S.; Qi, T.; Hu, G.P.; Zhao, H.X.; Li, J.; Wang, L.N. Desilication from titanium-vanadium slag by alkaline leaching. Trans. Nonferr. Met. Soc. 2013, 23, 3076-3082. [CrossRef]

3. Samal, S.; Mohapatra, B.K.; Mukherjee, P.S.; Chatterjee, S.K. Integrated XRD, EPMA and XRF study of ilmenite and titania slag used in pigment production. J. Alloys Compd. 2009, 474, 484-489. [CrossRef]

4. Zhang, J.L.; Xing, X.D.; Cao, M.M.; Jiao, K.X.; Wang, C.L.; Ren, S. Reduction kinetics of vanadium titano-magnetite carbon composite pellets adding catalysts under high temperature. J. Iron Steel Res. Int. 2013, 20, 1-7. [CrossRef]

5. Hou, T.; Zhang, Z.; Ye, X.; Encarnacion, J.; Reichow, M.K. Noble gas isotopic systematics of Fe-Ti-V oxide ore-related mafic-ultramafic layered intrusions in the Panxi area, China: The role of recycled oceanic crust in their petrogenesis. Geochim. Cosmochim. Acta 2011, 75, 6727-6741. [CrossRef]

6. Kothari, N.C. Recent developments in processing ilmenite for titanium. Int. J. Miner. Process. 1974, 1, $287-305$. [CrossRef]

7. Noguchi, H.; Natsui, S.; Kikuchi, T.; Suzuki, R.O. Reduction of $\mathrm{CaTiO}_{3}$ by electrolysis in the molten salt $\mathrm{CaCl}_{2}$-CaO. Electrochemistry 2018, 86, 82-87. [CrossRef]

8. Pan, F.; Zhu, Q.S.; Zhan, D.U.; Sun, H.Y. Oxidation kinetics, structural changes and element migration during oxidation process of vanadium-titanium magnetite ore. J. Iron Steel Res. Int. 2016, 23, 1160-1167. [CrossRef]

9. Han, G.H.; Tao, J.; Zhang, Y.B.; Huang, Y.F.; Guang-Hui, L.I. High-temperature oxidation behavior of vanadium, titanium-bearing magnetite pellet. J. Iron Steel Res. Int. 2011, 18, 14-19. [CrossRef]

10. He, S.; Sun, H.; Tan, D.G.; Peng, T. Recovery of titanium compounds from Ti-enriched product of alkali melting Ti-bearing blast furnace slag by dilute sulfuric acid leaching. Procedia Environ. Sci. 2016, 31, 977-984. [CrossRef]

11. Zhang, L.; Zhang, L.N.; Wang, M.Y.; Li, G.Q.; Sui, Z.T. Recovery of titanium compounds from molten Ti-bearing blast furnace slag under the dynamic oxidation condition. Miner. Eng. 2007, 20, 684-693. [CrossRef]

12. Niu, Y.; Du, X.; Yang, W.; Sui, Z. Flotation of the modified high titanium bf slag. J. Mater. Met. 2012, 11, 13-17. (In Chinese)

13. Li, J.; Zhang, Z.T.; Wang, X.D. Precipitation behaviour of Ti enriched phase in Ti bearing slag. Ironmak. Steelmak. 2000, 39, 414-418. [CrossRef]

14. Jiang, K.; Hu, X.; Ma, M.; Wang, D.; Qiu, G.; Jin, X.; Chen, G.Z. “Perovskitization”-assisted electrochemical reduction of solid $\mathrm{TiO}_{2}$ in molten $\mathrm{CaCl}_{2}$. Angew. Chem. Int. Ed. 2006, 45, 428-432. [CrossRef] [PubMed]

15. Lou, T.; Li, Y.H.; Li, L.S.; Sui, Z. Study of precipitation of perovskite phase from the oxide slag. Acta Metall. Sin. 2000, 36, 141-144. (In Chinese)

16. Li, L.; Sui, Z. Physical chemistry behavior of enrichment selectivity of $\mathrm{TiO}_{2}$ in perovskite. Acta Phys.-Chim. Sin. 2001, 17, 845-849. (In Chinese)

17. Wang, W.; Zhu, Y.; Zhang, S.; Deng, J.; Huang, Y.; Yan, W. Flotation behaviors of perovskite, titanaugite, and magnesium aluminate spinel using octyl hydroxamic acid as the collector. Minerals 2017, 7, 134. [CrossRef] 
18. Zhang, S. Study on High-Temperature Enrichment and Flotation Separation of Titanium Components from Ti-Bearing Blast Furnace Slag. Master's Thesis, Southwest University of Science and Technology, Mianyang, Sichuan, China, 2017; pp. 43-47. (In Chinese)

19. Meng, Q.; Feng, Q.; Shi, Q.; Ou, L. Studies on interaction mechanism of fine wolframite with octyl hydroxamic acid. Miner. Eng. 2015, 79, 133-138. [CrossRef]

20. Wu, X.Q.; Zhu, J.G. Selective flotation of cassiterite with benzohydroxamic acid. Miner. Eng. 2006, 19, 1410-1417. [CrossRef]

21. Liu, B.; Wang, X.; Du, H.; Liu, J.; Zheng, S.; Zhang, Y.; Miller, J.D. The surface features of lead activation in amyl xanthate flotation of quartz. Int. J. Miner. Process. 2016, 151, 33-39. [CrossRef]

22. Crumbliss, A.L. Iron bioavailability and the coordination chemistry of hydroxamic acids. Coord. Chem. Rev. 1990, 105, 155-179. [CrossRef]

23. Chen, G.L.; Tao, D.; Ren, H.; Ji, F.F.; Qiao, J.K. An investigation of niobite flotation with octyl diphosphonic acid as collector. Int. J. Miner. Process. 2005, 76, 111-122. [CrossRef]

24. Agrawal, Y.K. Hydroxamic acids and their metal complexes. Russ. Chem. Rev. 1979, 48, 948-963. [CrossRef]

25. Ni, X.; Liu, Q. The adsorption and configuration of octyl hydroxamic acid on pyrochlore and calcite. Colloids Surf. A 2012, 411, 80-86. [CrossRef]

26. Abaka-Wood, G.B.; Addai-Mensah, J.; Skinner, W. A study of selective flotation recovery of rare earth oxides from hematite and quartz using hydroxamic acid as a collector. Adv. Powder Technol. 2018, 29, 1886-1899. [CrossRef]

27. Pavez, O.; Brandao, P.R.G.; Peres, A.E.C. Adsorption of oleate and octyl-hydroxamate on to rare-earths minerals. Miner. Eng. 1996, 9, 357-366. [CrossRef]

28. Zhang, W.; Honaker, R.Q.; Groppo, J.G. Flotation of monazite in the presence of calcite part I: Calcium ion effects on the adsorption of hydroxamic acid. Miner. Eng. 2017, 100, 40-48. [CrossRef]

29. Zhang, W.; Honaker, R.Q. Flotation of monazite in the presence of calcite part II: Enhanced separation performance using sodium silicate and EDTA. Miner. Eng. 2018. [CrossRef]

30. Xu, L.; Tian, J.; Wu, H.; Lu, Z.; Yang, Y.; Sun, W.; Hu, Y. Effect of $\mathrm{Pb}^{2+}$ ions on ilmenite flotation and adsorption of benzohydroxamic acid as a collector. Appl. Surf. Sci. 2017, 425, 796-802. [CrossRef]

31. Fan, X.; Rowson, N.A. The effect of $\mathrm{Pb}\left(\mathrm{NO}_{3}\right)_{2}$ on ilmenite flotation. Miner. Eng. 2000, 13, 205-215. [CrossRef]

32. Li, H.; Mu, S.; Weng, X.; Zhao, Y.; Song, S. Rutile flotation with $\mathrm{Pb}^{2+}$ ions as activator: Adsorption of $\mathrm{Pb}^{2+}$ at rutile/water interface. Colloids Surf. A 2016, 506, 431-437. [CrossRef]

33. Han, H.; Hu, Y.; Sun, W.; Li, X.; Cao, C.; Liu, R.; Yue, T.; Meng, X.; Guo, Y.; Wang, J. Fatty acid flotation versus BHA flotation of tungsten minerals and their performance in flotation practice. Int. J. Miner. Process. 2017, 159, 22-29. [CrossRef]

34. Liu, C.; Feng, Q.; Zhang, G.; Ma, W.; Meng, Q.; Chen, Y. Effects of lead ions on the flotation of hemimorphite using sodium oleate. Miner. Eng. 2016, 89, 163-167. [CrossRef]

35. Yang, S.; Qiu, X.; Peng, T.; Chang, Z.; Feng, Q.; Zhong, C. Beneficial effects and mechanism of lead ion on wolframite flotation. Physicochem. Probl. Miner. Process. 2016, 52, 855-873.

36. Kay, H.F.; Bailey, P.C. Structure and properties of $\mathrm{CaTiO}_{3}$. Acta Crystallogr. 1957, 10, 219-226. [CrossRef]

37. Mehdilo, A.; Irannajad, M.; Rezai, B. Effect of crystal chemistry and surface properties on ilmenite flotation behavior. Int. J. Miner. Process. 2015, 137, 71-81. [CrossRef]

38. Fan, X.; Waters, K.E.; Rowson, N.A.; Parker, D.J. Modification of ilmenite surface chemistry for enhancing surfactants adsorption and bubble attachment. J. Colloid Interface Sci. 2009, 329, 167-172. [CrossRef] [PubMed]

39. Kurzak, B.; Kozłowski, H.; Farkas, E.; Kurzak, B.; Kozłowski, H.; Farkas, E. Hydroxamic and aminohydroxamic acids and their complexes with metal ions. Coord. Chem. Rev. 1992, 114, 169-200. [CrossRef]

40. Sreenivas, T.; Padmanabhan, N.P.H. Surface chemistry and flotation of cassiterite with alkyl hydroxamates. Colloids Surf. A Physicochem. Eng. Asp. 2002, 205, 47-59. [CrossRef]

41. Marabini, A.M.; Ciriachi, M.; Plescia, P.; Barbaro, M. Chelating reagents for flotation. Miner. Eng. 2007, 20, 1014-1025. [CrossRef]

42. Zhang, W.; Honaker, R. A fundamental study of octanohydroxamic acid adsorption on monazite surfaces. Int. J. Miner. Process. 2017, 164, 26-36. [CrossRef]

43. Meng, Q.; Yuan, Z.; Yu, L.; Xu, Y.; Du, Y. Study on the activation mechanism of lead ions in the flotation of ilmenite using benzyl hydroxamic acid as collector. J. Ind. Eng. Chem. 2018, 62, 209-216. [CrossRef] 
44. Han, H.S.; Liu, W.L.; Hu, Y.H.; Sun, W.; Li, X.D. A novel flotation scheme: Selective flotation of tungsten minerals from calcium minerals using Pb-BHA complexes in Shizhuyuan. Rare Met. 2017, 36, 533-540. [CrossRef]

45. Ouerd, A.; Alemany-Dumont, C.; Berthomé, G.; Normand, B.; Szunerits, S. Reactivity of titanium in physiological medium I. Electrochemical characterization of the metal/protein interface. J. Electrochem. Soc. 2007, 35, C593-C601. [CrossRef]

46. Soccol, D.; Martens, J.; Claessens, S.; Fransaer, J. Effect of carbon modification of particles on their incorporation rate during electrodeposition. J. Electrochem. Soc. 2011, 158, D515-D523. [CrossRef]

47. Feng, Q.; Zhao, W.; Wen, S.; Cao, Q. Activation mechanism of lead ions in cassiterite flotation with salicylhydroxamic acid as collector. Sep. Purif. Technol. 2017, 178, 193-199. [CrossRef]

C 2018 by the authors. Licensee MDPI, Basel, Switzerland. This article is an open access article distributed under the terms and conditions of the Creative Commons Attribution (CC BY) license (http:/ / creativecommons.org/licenses/by/4.0/). 